\title{
WAC Gene
}

National Cancer Institute

\section{Source}

National Cancer Institute. WAC Gene. NCI Thesaurus. Code C134034.

This gene is involved in chromatin remodeling and DNA damage responses. 